\title{
Mud volcano gas hydrates in the Caspian Sea
}

\author{
G.D.GINSBURG \& V. A.SOLOVIEV
}

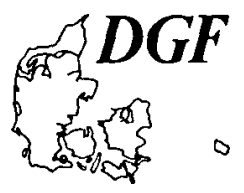

\author{
Ginsburg, G. D. \& Soloviev, V. A.: Mud volcano gas hydrates in the Caspian Sea. Bulletin of the \\ Geological Society of Denmark, Vol. 41, pp. 95-100. Copenhagen, 1994-03-30. \\ https://doi.org/10.37570/bgsd-1995-41-10
}

\begin{abstract}
Two gas hydrate accumulations associated with mud volcano craters were investigated by means of sparker survey, bottom water and sediment sampling using gravity corer and subsequent chemical and isotopic studies of gas, bottom and porewater and carbonate inclusions. Hydrate contents in sediments were up to $35 \%$ per volume. Sometimes hydrates were encountered immediately on the seabed. Correlations have been established between hydrate contents, water contents (after dissociation of hydrates), chlorinity and the oxygen and hydrogen isotope composition of the pore water. The hydrate water is enriched with respect to deuterium. Liquid water in sediments contains higher ${ }^{18} 0$ as result of isotopic exchange with carbonates. Hydrates are thought to have formed from the mud volcano brines (from their water and from dissolved light hydrocarbons which are thermogenic in origin). Each accumulation has its own deep source. The developed approach presents a thorough study of the hydrate and water contents in sediments along with the water composition.
\end{abstract}

G. D. Ginsburg \& V. A. Soloviev, Research Institute for Geology and Mineral Resources of the Ocean, 1 pr. Maklina, St. Petersburg, 190121, Russia. August 23rd, 1992.

\section{Introduction}

Mud volcanoes, carrying hydrocarbon gases to the surface, are very suitable for the study of natural gas hydrate formation when they occur in the deep-sea environments where thermobaric conditions are favorable for hydrate stability. Over 60 rises, potentially associated with mud volcanoes are known in the southern deep-water basin of the Caspian Sea (Fig. 1). Two expeditions have been carried out to search and investigate the gas hydrate accumulations associated with these volcanoes (Ginsburg et al. 1988, 1992). The results of a geochemical study on the nature of hydrate-generating fluids and mechanisms of hydrate formation are described here.

\section{Methods}

To locate the craters of mud volcanoes, a sparker survey operating at $200-800 \mathrm{~Hz}$ was used. Sediment cores were obtained with a $1.2 \mathrm{~m}$ long gravity corer having a 100 $\mathrm{mm}$ diameter soft polyethylene core liner. Bottom-water samples were taken from the corer's headband. As each core was removed from the core barrel, the liner was cut along the lenght and the core was inspected. If gas hydrates were observed, their volumetric content in the sediment was evaluated visually. Several times we also estimated the gas hydrate content by measuring the volume of water and gas which was liberated from decom- posed hydrate; it is clear that the values obtained are underestimated.

To obtain gas samples from dissociating hydrates, hydrate-bearing sediments were placed in water saturated with sodium chloride, and the released gas was collected by trapping in a water-filled, inverted glas bottle. Two gas samples have been taken after complete decomposition of hydrate aggregates in steel containers, also using a glas bottle.

Equivalent subsamples were taken to determine water content after hydrate decomposition and to obtain water samples for subsequent analyses. For water content determination (by weight), samples were kept in a drying cabinet under a temperature of $105{ }^{\circ} \mathrm{C}$ until steady weight. We calculated water content versus weight of wet sediment. Water samples were obtained using a screw press to force water through coarse filter paper.

Gas samples were analysed using chromatographic system of Soviet model LKhM-8MD with a thermal conductivity detector. Chemical analyses of water followed the procedures of Reznikov et al. (1963). Chloride ion concentrations were determined by means of the silver nitrate titration method and magnesium ion by the trilon B titration method.

The isotopic composition of carbon of $\mathrm{C}_{1}-\mathrm{C}_{4}$ in gas samples was analysed using a Varian Mat 230 mass spectrometer. Preliminary separation of hydrocarbons was carried out by chromotography. The carbon and oxygen isotopes of the sediment carbonates were analysed on a GD-150 Varian Mat mass spectrometer with an 


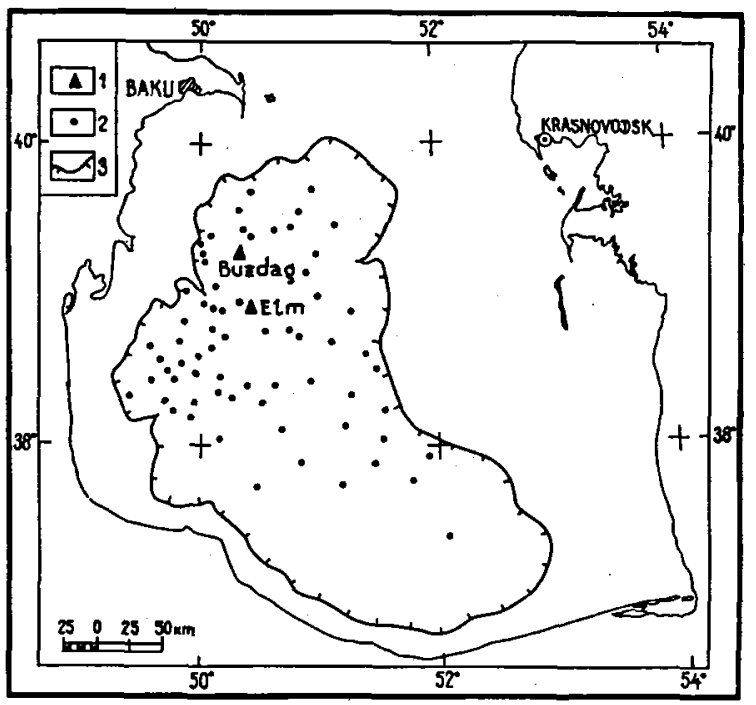

Fig. 1. Location of studied gas hydrate accumulations (1) and assumed mud volcanoes (2, after Yakubov et al. 1989) in the deep Southern Caspian Sea. $3-250 \mathrm{~m}$ isobath (the upper limit of gas hydrate-bearing mud volcanoes).

error of $<0.1 \%$ for carbon and $0.2 \%$ o for oxygen. Carbon dioxide was extracted from carbonates by orthophosphoric acid treatment according to the method described by McCrea (1950). The same mass spectrometer was used to determine the oxygen and hydrogen isotopic compositions of water samples. Analytical methods were described by Iesikov (1980).

\section{Geological setting}

Gas hydrates have been discovered in the crater fields of two mud volcanoes: Buzdag and Elm (see Fig. 1), $475 \mathrm{~m}$ and $660 \mathrm{~m}$ deep, respectively. The diameters of the crater fields are about $0.5 \mathrm{~km}$ and $4.0 \mathrm{~km}$, respectively. In both cases hydrates were observed in clay breccia as ice-like semi-transparent mat inclusions of various shapes and sizes. Irregular plates up to several $\mathrm{mm}$ thick and up to 12 $\mathrm{cm}$ long, subisometric angular pieces up to $5 \mathrm{~cm}$ and very small scales and needles were found. Plate-like inclusions were sometimes subhorizontally oriented and produced the lenticular structure of the sediments. Inclusions oriented differently were also encountered.

Hydrates were observed in 19 cores out of 20 recovered from the Buzdag crater field and in 5 out of 7 from the eastern part of the Elm. The hydrate content in the sediments varied from 2-3\% up to $35 \%$ in Buzdag sediments and up to $15 \%$ in Elm and usually there was no spatial regularity. Only one core from Elm contained hydrate in the upper $30 \mathrm{~cm}$. At several sites in Buzdag, hydrates obviously rest immediately on the seabed: numerous "hailstones" of hydrate up to 3-4 mm in diameter were poured out of the corer's head together with seawa- ter. It is evident that hydrate can be preserved on the seabed if hydrate-forming gas is continuously supplied.

Yellowish-green paraffin-naphthene base oil associated with hydrate was recovered in cores from Buzdag. In cores from both mud volcanoes, carbonate inclusions and, less frequently, sulphur-carbonate inclusions were observed. The isotopic composition of carbonate carbon ( $\delta^{13} \mathrm{C}$ from -4.4 to $-28.9 \%$ PDB) suggests that the inclusions were formed from carbon by oxidation of organic matter.

\section{Water content in sediments}

The water content of hydrate-bearing clay breccias after hydrate decomposition varied from $33.5 \%$ up to $44.2 \%$.

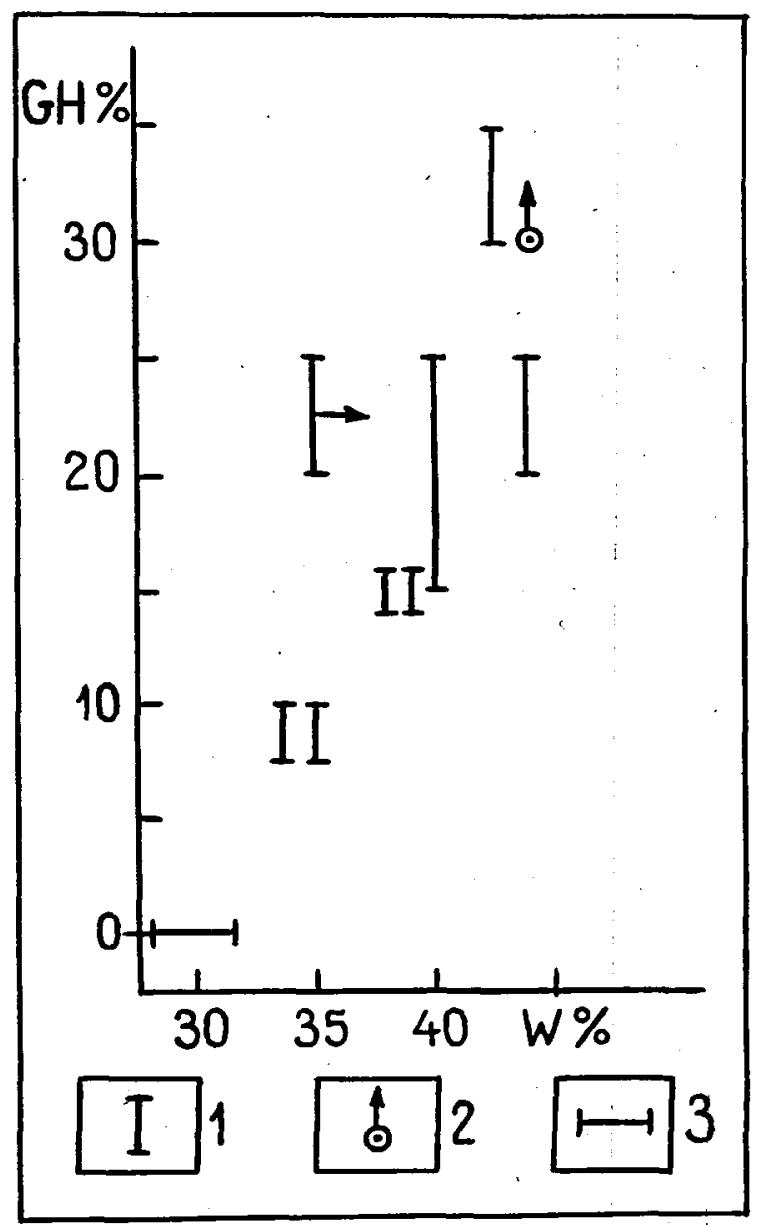

Fig. 2. Relationship between gas hydrate content $(\mathrm{GH}$, volume $\%$ ) and water content (weight \%) of clay breccia. 1 - limits of visually estimated values of gas hydrate content; arrow indicates that water content was artificially understated due to removal of gas hydrate aggregates; 2 - gas hydrate content was estimated by measuring of water released after hydrate decomposition (understated value); 3 - limits of water content in clay breccia without gas hydrate. 


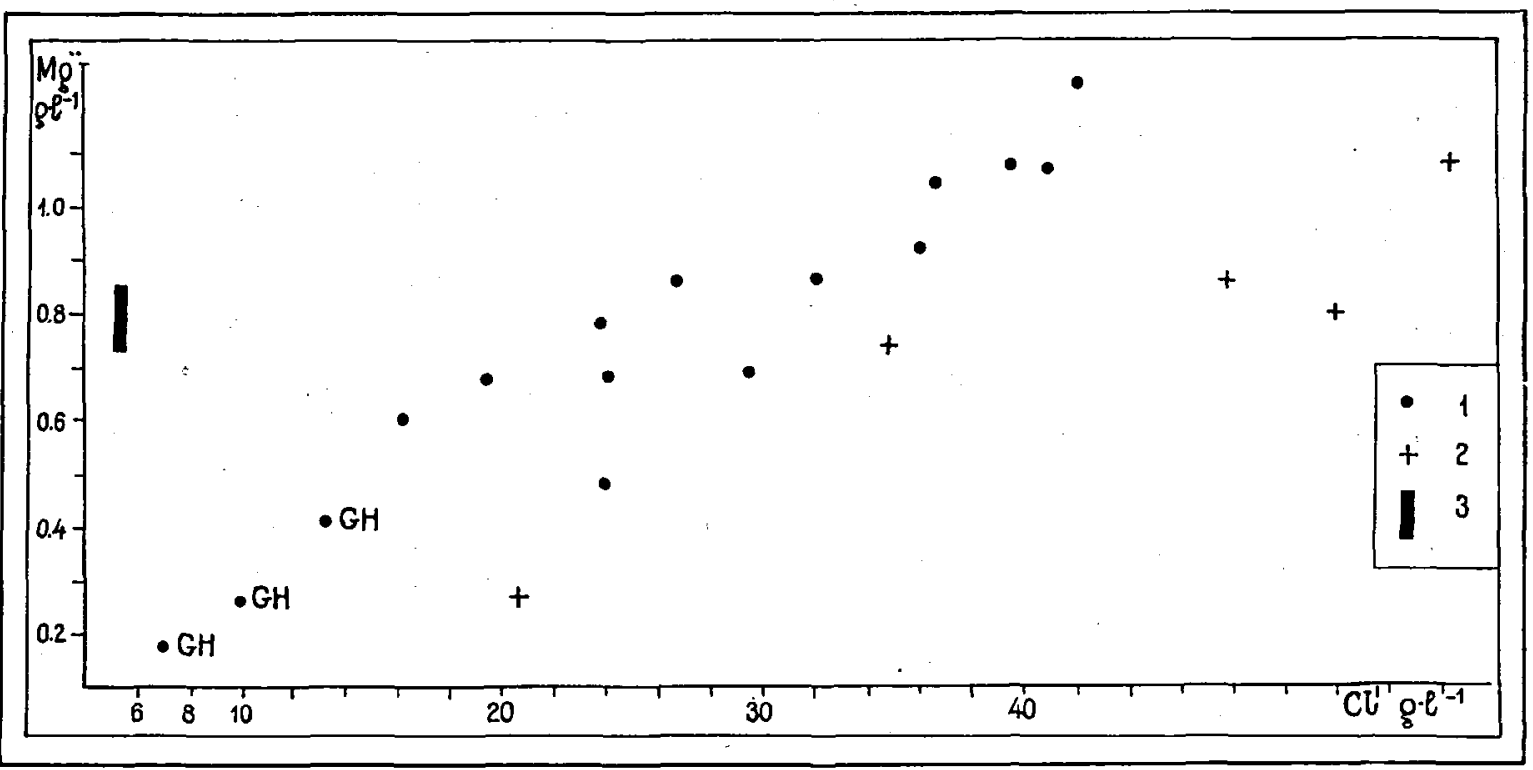

Fig. 3. Chlorinity and magnesium content in sea water, water of gas hydrate-bearing sediments and of gas hydrate (GH). 1 - Buzdag, 2 - Elm, 3 - sea water.

This is less than that of normal stratified bottom sediments in the southern Caspian Sea (about 60\%) but more than that of clay breccia without hydrate $(28.0 \%-31.5 \%)$. There exists a correlation between water and hydrate contents (Fig. 2). This suggests that when hydrate forms it does not use pore water of the clay breccia itselff, but accumulates water from elsewhere.

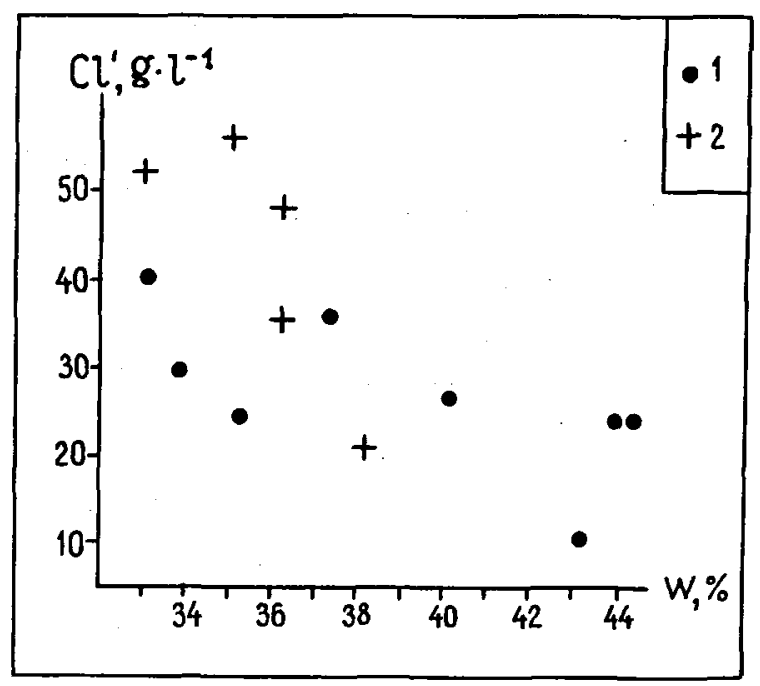

Fig. 4. Relationship between chlorinity of water extracted from gas hydrate-bearing sediments and their water content. 1 Buzdag, 2 - Elm.

\section{Water salinity and chlorinity}

The chlorinity of the bottom water samples was 5.4 to 5.5 $\mathrm{g} / \mathrm{l}$, i.e. salinity was 13.0 to $13.2 \mathrm{~g} / \mathrm{l}$. Water samples from melted hydrate turned out to have higher concentrations; their chlorinity was 7.1 to $13.4 \mathrm{~g} / \mathrm{l}$, i.e. salinity was 13.7 to $23.2 \mathrm{~g} / \mathrm{l}$. Inasmuch as crystallization of hydrate eliminates salts, the salinity of the hydrate water suggests that either contamination with pore water of hydrate-bearing sediments takes place during the sampling or brine cells occur in hydrate aggregates, since the salinity of hydrate water is higher than that of sea water, sea water could not be a source for hydrate. The distinctive nature of these two waters reveals itself also when we compare the relations between concentrations of the two characteristic ions: magnesium and chloride (Fig. 3).

Fig. 3 makes it possible to arrive at the following conclusions:

- Waters in hydrate-bearing sediments of Buzdag and Elm being more concentrated than hydrate waters also differ from the modern Caspian Sea water and form independent groups. Very likely they come from different sources.

- The major cause of the variability of salt concentration in the studied water samples of each hydrate-bearing mud volcano is simple dilution - concentration.

This makes it clear that hydrates accumulate from mud volcanic brines and that dilution of brines is caused by melting hydrates. The higher the amount of hydrate in the 


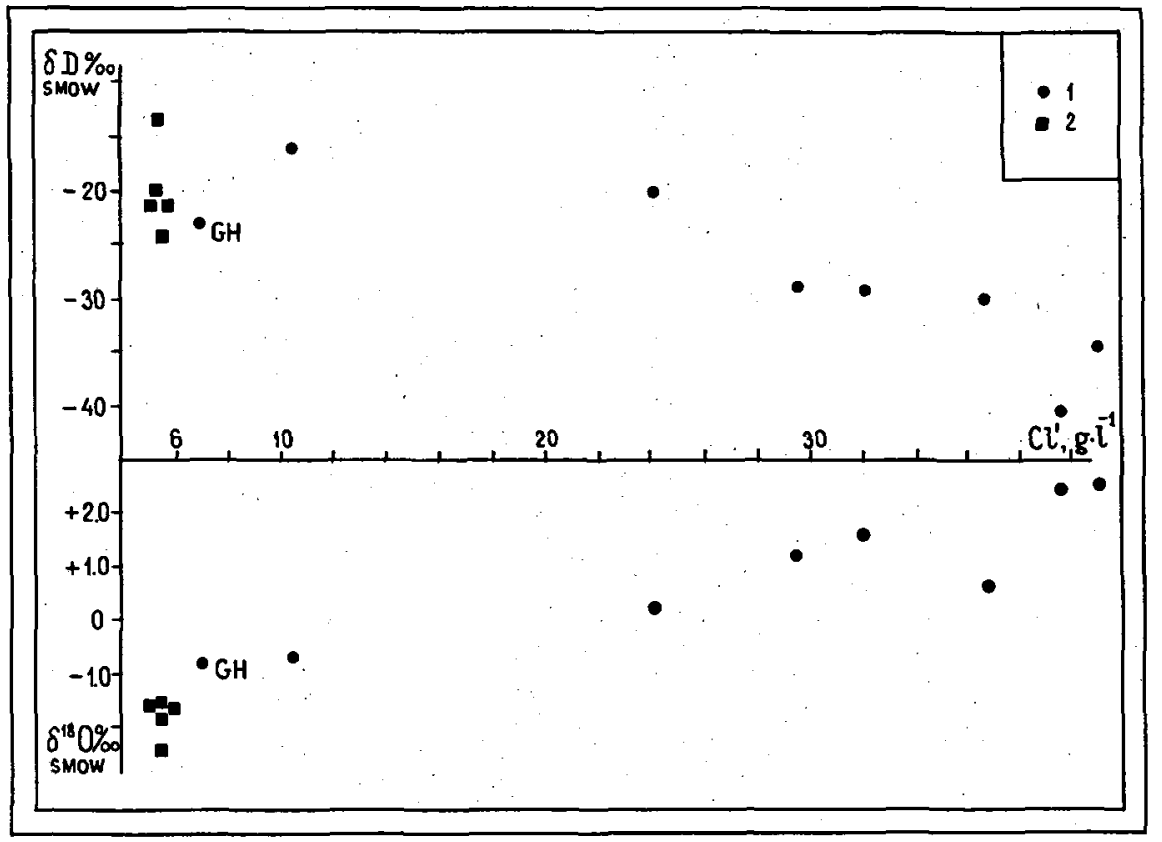

Fig. 5. Relationship between $\mathrm{H}$ and $\mathrm{O}$ isotopic composition and water chlorinity. 1 - gas hydratebearing sediments and gas hydrate (GH) of Buzdag; 2 sea water.

sediments, the lower is the water salinity after hydrate dissociation.

The influence of melting hydrate on water freshness is shown to be correct by the negative correlation between water chlorinity and water content of hydrate-bearing sediments (Fig. 4) which, as was mentioned above, may be considered as an indicator of hydrate content (see Fig. 2). Thus, the model "pore water chlorinity as an indicator of hydrate content" (Hesse \& Harrison 1981) is corroborated here.

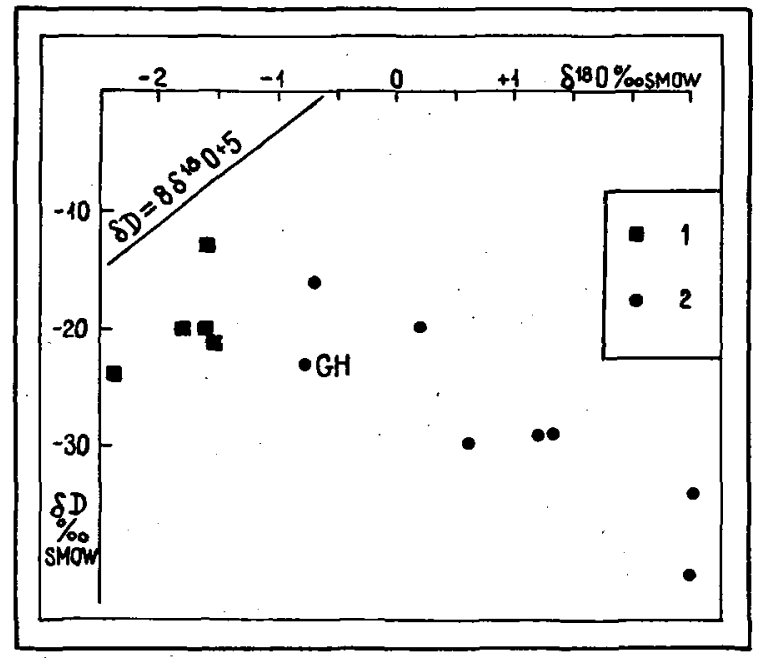

Fig. 6. Relationship between $\mathrm{H}$ and $\mathrm{O}$ isotopic composition of water. Solid straight line is Craig's line (Hoefs 1980), other conventional signs see Fig. 5.

\section{Isotopic composition of water oxygen and hydrogen}

It is known that enrichment in the heavy isotope of oxygen $\left({ }^{18} 0\right)$ of hydrate phase compared with water results from gas hydrate formation (Davidson et al. 1983; Handa 1984). Hydrogen isotopes (D,H) are also thought to be fractionated (Tsarev et al. 1974). Taking this into consideration we describe and interpret the results of the isotopic study of our samples as follows (Figs 5 and 6):

- A correlation between $\delta^{18} 0, \delta \mathrm{D}$ and chlorinity of water from hydrate-bearing sediments is observed. The variability of these parameters seems controlled by conjugate processes.

- Probably $\delta D$ varies under the influence of hydrate formation: relatively fresh samples (presumably containing more hydrate water) are enriched with deuterium.

- The measured trend of $\delta^{18} 0$ variability is opposite to that expected from the idea that fractionation is caused by hydrate formation and, instead, may result from isotopic exchange between water and carbonates (Drever 1982; Hoefs 1980). Indeed, oxygen of carbonates from hydrate-bearing clay breccia of Buzdag is much heavier than oxygen of water - it varies from 27.0 up to $35.6 \%$ SMOW. However, how can one explain the conjunction between such an exchange and hydrate accumnulation?

The lower the amount of water versus the amount of carbonate and the longer the water contact with carbon-

Bulletin of the Geological Society of Denmark 
Table 1. Composition of gas from gas hydrate-bearing sediments

\begin{tabular}{|c|c|c|c|c|c|c|c|c|c|c|c|c|}
\hline \multirow{2}{*}{$\begin{array}{l}\text { Mud } \\
\text { volcano }\end{array}$} & \multirow{2}{*}{$\begin{array}{c}\Sigma \mathrm{C}_{\mathrm{n}}+\mathrm{CO}_{2} \\
\%\end{array}$} & \multicolumn{7}{|c|}{ Composition of gas, \% relatively $\Sigma\left(\mathrm{C}_{\mathrm{n}}+\mathrm{CO}_{2}\right)$} & \multicolumn{4}{|c|}{$\delta{ }^{13} \mathrm{C} \%$} \\
\hline & & $\mathrm{C}_{1}$ & $\mathrm{C}_{2}$ & $\mathrm{C}_{3}$ & $\mathrm{iC}_{4}$ & $\mathrm{nC}_{4}$ & $\mathrm{C}_{5+}$ & $\mathrm{CO}_{2}$ & $C_{1}$ & $\mathrm{C}_{2}$ & $\mathrm{C}_{3}$ & $\mathrm{C}_{4}$ \\
\hline Buzdag & $\begin{array}{l}99.0 \\
93.4\end{array}$ & $\begin{array}{l}74.7 \\
76.0\end{array}$ & $\begin{array}{l}17.4 \\
19.3\end{array}$ & $\begin{array}{l}2.4 \\
2.4\end{array}$ & $\begin{array}{l}0.4 \\
0.6\end{array}$ & $\begin{array}{l}1.1 \\
0.3\end{array}$ & $\begin{array}{l}0.33 \\
0.05\end{array}$ & $\begin{array}{l}3.6 \\
1.2\end{array}$ & $\begin{array}{c}-44.8 \\
\text { n.a. }\end{array}$ & $\begin{array}{c}-26.0 \\
\text { n.a. }\end{array}$ & $\begin{array}{c}-22.1 \\
\text { n.a. }\end{array}$ & $\begin{array}{c}-20.9 \\
\text { n.a. }\end{array}$ \\
\hline Elm & $\begin{array}{l}99.5 \\
43.0\end{array}$ & $\begin{array}{l}95.3 \\
81.4\end{array}$ & $\begin{array}{r}0.6 \\
15.3\end{array}$ & $\begin{array}{l}1.6 \\
1.6\end{array}$ & $\begin{array}{l}1.7 \\
0.2\end{array}$ & $\begin{array}{l}\text { n.d. } \\
0.7\end{array}$ & $\begin{array}{c}0.01 \\
\text { n.d. }\end{array}$ & $\begin{array}{l}0.9 \\
0.8\end{array}$ & $\begin{array}{c}-56.0 \\
\text { n.a. }\end{array}$ & $\begin{array}{c}-27.0 \\
\text { n.a. }\end{array}$ & $\begin{array}{c}-7.8 \\
\text { n.a. }\end{array}$ & $\begin{array}{c}-30.8 \\
\text { n.a. }\end{array}$ \\
\hline
\end{tabular}

n.a. $=$ not analyzed

n.d. $=$ not detected

ate, the stronger is the effect of exchange on the isotopic composition of water (Drever 1982). Although we did not study the amount of carbonates in the sediments and the duration of their contact with water, existing data seem to correspond to this model. They suggest that hydrate is accumulating in sediments immediately along the brine infiltration routes and simultaneously water is being enriched with ${ }^{18} 0$ in the peripheral part of the brine flow. If hydrate accumulates from infiltering brine, the hydrate content may be considered as a measure of the amount of water which has passed through the sediment during hydrate formation or as a measure of water infiltration rate. In other words, in sediment where the hydrate content is smaller, the water is in contact with carbonates longer and accumulates more ${ }^{18} 0$. On the other hand, carbonates which are considered as an oxidation product of hydrocarbons migrating along with brine (Brooks et al. 1986) seem to form preferentially near the boundaries of the brine flow. Thus conditions for enrichment of water in ${ }^{18} 0$ on account of exchange with carbonates are better in sediments with small hydrate contents.

Thus, isotopic data on the whole are in conformity with the model by which hydrate accumulates in sediments on account of infiltering mud volcanic brine. The conditions for oxidation of hydrocarbons and the consequent formation of carbonates are anticipated to become worse with increasing subbottom depth. Thus, the behaviour of $\delta^{18} 0$ in the water will unconditionally change.

\section{Composition of gas}

Gases which are released freely from hydrate-bearing sediments are essentially hydrocarbonic and contain considerable amounts of methane homologues (Table 1) suggesting a thermogenic gas origin. This is supported by the heavy isotopic composition of methane (Table 1) and the association with oil. Judging the $\delta^{13} \mathrm{C}-\mathrm{CH}_{4}$ values, the source of hydrate-forming fluids in the studied areas occur at different depths (see also hydrogeochemical data: comments to Fig. 3) and the source of the Buzdag fluid is deeper.

\section{Conclusions}

Gas hydrates discovered in crater fields of two mud volcanoes in the Caspian Sea are formed from infiltrating fluids: volcanic brines and thermogenic gases. It is very probably that hydrate-forming gas arrives dissolved in brine.

Since the genesis of submarine gas hydrate is poorly understood in general and since filtrogenic hydrates are thought to be most widespread (Soloviev \& Ginsburg, this volume), it will be useful to study relatively accessible hydrate accumulations associated with submarine seepage like the ones investigated in the Caspian Sea in order to figure out the mechanisms of hydrate formation. There are similar or very close conditions in several regions where gas hydrates occur: the Gulf of Mexico (Brooks et al. 1986), offshore California (Brooks et al. 1991), the Black Sea (Ginsburg et al. 1990) and the Okhotsk Sea (Ginsburg et al. 1993). The approach developed in this paper appears to be useful in the future for a quantitative description of hydrate-forming processes.

\section{Dansk sammendrag}

To forekomster af gashydrater i forbindelse med undersøiske mudder vulkaner er blevet undersøgt i det Caspiske Hav på relativt lavt vand, dvs. på henholdsvis $475 \mathrm{~m}$ og 650 meters vanddybde. Gashydrater var tilstede $i$ adskillige borekerner i overfladenære sedimenter. Sedimentprøverne havde karakter af "mudderbreccie", idet de indeholdt op til 35 vol\% gashydrat $i$ form af uorienterede plade- til linseligende inklusioner af hydrat. I enkelte tilfælde blev der fundet hydrat i direkte forbindelse med havbunden. Det synes derfor muligt, at gashydrat kan være stabilt i vand-sediment interfasen, såfremt der er en kontinuerlig tilførsel af hydrat-dannende gas. I forbindelse med gashydraterne blev der også fundet gasrelateret karbonatudfældning i sedimenterne.

Analyser chloridindholdet $\mathrm{i}$ gashydraternes vandfase og sammensætningen af hydrogen- og iltisotoperne i den tilhørende gasfase tyder på, at gashydraterne formodentligt er dannet ved tilførsel af gasmættet porevand fra 
dybere liggende formationer $i$ forbindelse med mudder vulkanismen.

\section{Acknowledgements}

The authors express their thanks to I. S. Guliyev and R. A. Guseinov for the excellent opportunity to study the submarine gas hydrates they provided. We highly appreciate the contribution of Ie. V. Telepnev, G. A. Ivanova, S.P.Saveliev, V. A. Krotov, Ch.S. Muradov and A. A. Dadashev who fruitfully participated in the expeditions, as well as A. D. Iesikov, I. Yu. Shabaieva, V. I. Mal'tseva and N.K.Gornovskaya which carried out analyses of water and gas samples. We are most grateful to Dr. Tj.C. E. van Weering for the careful review of the manuscript.

\section{References}

Brooks, J. M., Cox, H. B., Bryant, W. R., Kennicutt, M. C. II, Mann, R. G. \& McDonald, T. J. 1988: Association of gas hydrates and oil seepage in the Gulf of Mexico. Org. Geochem., 10, 221-234.

Brooks, J. M., Field, M. E. \& Kennicutt, M. C. II 1991: Observations of gas hydrates in marine sediments, offshore northern California. Marine Geology, 96, 103-109.

Davidson, D. W., Least, D. G. \& Hesse, R. 1983: Oxygen-18 enrichment in the water of a clathrate hydrate. Geochim. et Cosmochim. Acta. 47, 12, 2293-2295.

Drever, J. I. 1982: The geochemistry of natural waters. PrenticeHall, Inc., Englewood Cliffs, N. J. 07632.

Ginsburg, G. D., Gramberg, I. S., Guliyev, I. S., Guseinov, R. A., Dadashev, A. A., Ivanov, V. L., Krotov, A. G., Muradov, Ch. S., Soloviev, V. A. \& Telepniev, Ie. V. 1988.: Subaqueous mud volcanic type of gas hydrate accumulations. Doklady Akademii Nauk SSSR 300, 2: 418-418 (in Russian).
Ginsburg, G. D., Kremlev, A. N., Grigorév, M. N., Larkin, G. V., Pavlenkin, A. D., Saltykova, N. A. 1990: Filtrogenic gas hydrates in the Black Sea (twenty-flrst voyage of the research vessel "Evpatoriya"). Soviet geology and geophysics (Geologiya i Geofizika) 31, 3, Allerton Press, 8-16.

Ginsburg, G. D., Guseinov, R. A., Dadashev, A. A., Ivanova, G. A., Kazantsev, S: A., Soloviev, V. A., Telepniev, Ie. V., Askeri-Nasirov, R. E., Iesikov, A. D., Mal'tseva, V. I., Mashirov, Yu. G. \& Shabaieva, I. Yu. 1992: Gas hydrates in the Southern Caspian Sea. Izvestiya Akademii Nauk, Seriya Geologicheskaya, 7, 5-20 (in Russian).

Ginsburg, G. D., Soloviev, V. A., Cranston, R. E., Lorenson, T. - D. \& Kvenvolden, K. A. 1993: Gas hydrates from the continental slope offshore from Sakhalin Island, Okhotsk Sea. Geo-Marine Letters, 13, 41-48.

Handa G. P. 1984: Enthalpies of fusion and heat capacities for $\mathrm{H}_{2}{ }^{18} \mathrm{O}$ ice and $\mathrm{H}_{2}{ }^{18} \mathrm{O}$ tetrahydrofuran clathrate hydrate in the range $100-270 \mathrm{~K}$. Canad. Journ. of Chem. 82, 9, 1859-1861.

Hesse R. \& Harrison W. E. 1981: Gas hydrates (clathrates) causing pore water freshening and oxygen isotope fractionation in deep-water sedimentary sections of terrigenous continental margins. Earth and Planet. Sci. Letters 55, 453-462.

Hoefs, J. 1980: Stable isotope geochemistry. Sec. edition. Springer-Verlag Berlin Heidelberg New York, pp. 208.

Iesikov, A. D. 1980: Mass-spectrometric analysis of natural waters. Moskva Nauka, 204 p. (in Russian).

Mc Crea, J. M. 1950: The isotopic chemistry of carbonates and a paleotemperature scale. J.Chem.Phys., 18, p. 849-857.

Reznikov, A. A., Mulikovskaya, Ye P. \& Sokolov, I. Yu. 1963: The methods of natural water analysis. Moskva Gosgeoltekhizdat, 404 p. (in Russian).

Soloviev, V. A. \& Ginsburg, G. D.: Formation of submarine gas hydrates. This issue.

Tsariev V. P., Groisman A. G., Savvin A. Z. 1974: The mechanism of isotope fractionation within the zones of gas hydrate formation. Pyatyj vsesoyuznyj simpozium po geokhimii stabil'nykh izotopov. Tezisy dokladov. Chast, I. Moskva, 34-36 (in Russian).

Yakubov A. A., Dadashev F. G., Mekhtiiev A. K. 1989: Regulations governing mud volcanoes distribution in the Caspian Sea. Geologo-geofizicheskie issledovaniya Kaspijskogo morya. Moskva Nauka, $70-72$ (in Russian). 